\title{
Anatomical characteristics and nutrient uptake and distribution associated with the Cd-phytoremediation capacity of Eucalyptus camaldulenses Dehnh
}

\author{
M.P. Gomes ${ }^{1,3^{*}}$, T.C.L.L.S.M. Marques², M.M.L.C. Carneiro ${ }^{3}$, Â.M. Soares ${ }^{3}$ \\ ${ }^{1}$ Université du Québec à Montréal, Institut des Sciences de l'environnement, Succ. Centre-Ville, C.P. 8888,

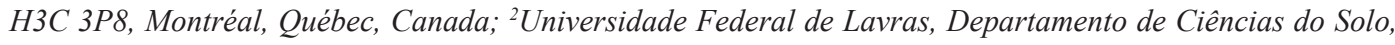 \\ Campus UFLA, 37200-000, Lavras, MG, Brazil; ${ }^{3}$ Universidade Federal de Lavras, Departamento de Biologia, \\ Campus UFLA, 37200-000, Lavras, MG, Brazil. *Corresponding author: marcelopgom@yahoo.com.br;
}

\begin{abstract}
Cadmium (Cd) is a hazardous heavy metal whose concentrations have been increasing in Brazilian soils, largely due to mining activities. Eucalyptus species are widely planted in Brazil to produce raw materials, and the confirmation of their phytoremediation potential would link their economic and environmental roles. We examined the Cd-tolerance of Eucaliptus camaldulenses Dehnh and the anatomical and physiological features associated with that capacity. Plants were grown under greenhouse conditions in nutrient solutions with increasing concentrations of $\mathrm{Cd}(0,15,25,45$, $90 \mu \mathrm{mol} \mathrm{m} \mathrm{m}^{-3}$. Shoot biomass production was less sensitive to the phytotoxic effects of cadmium than root biomass production due to low $\mathrm{Cd}$ transport rates from roots to shoots. Increases in epidermal and endodermal thickness, changes in the vascular conductive elements of the roots, as well as differential nutrient distributions between roots and shoots are features of $\mathrm{Cd}$ tolerance in this species. The $\mathrm{Cd}$ tolerance of $E$. camaldulenses and its high biomass production support its potential use in $\mathrm{Cd}$ phytoremediation programs.
\end{abstract}

Keywords: heavy metal; mineral nutrition; phytotoxicity; root anatomy; Cd-uptake. 


\section{Introduction}

Phytoremediation is an environmentally friendly technique and often represents the most cost-effective treatment for metal-polluted soils - especially in cases of extensive pollution (Dary et al., 2010). The use of woody species in phytoremediation programs has been increasing, and a better understanding of the biological processes of heavy metal absorption, translocation, and accumulation, tolerance mechanisms, and phytotoxicity symptoms could improve this already useful technology.

Heavy metal contamination and its consequences for environmental quality and safety are now wellknow global problems (Sharma and Agrawal, 2006). Among the hazardous metals, cadmium (Cd) is of particular concern because of its high toxicity to living organisms; Cd has no known biological function but shows high mobility in the soil - leading to Cd accumulation by plants and thus in the entire food chain (Yang, et al., 1996). In Brazil, particularly in Minas Gerais State (MG), background Cd concentrations in soils are increasing, principally due to mining and agricultural activities.

Uptake of heavy metals from soils depends on their concentrations, bioavailability, presence of organic matter, $\mathrm{pH}$, redox potential, temperature, fertilizer cations, and other factors (Bernal et al., 2009). Much is already known about the bioaccumulation, toxicity, and Cd-adsorption by plants (Marchial et al., 1996; Sharma and Agrawal, 2006). Cd competition with macro- and micronutrients such as phosphorus $(\mathrm{P})$, calcium $(\mathrm{Ca})$, magnesium $(\mathrm{Mg})$, iron $(\mathrm{Fe})$, manganese $(\mathrm{Mn})$, copper $(\mathrm{Cu})$, zinc $(\mathrm{Zn})$, and nickel $(\mathrm{Ni})$ for the same transmembrane carrier proteins (Rivetta et al., 1997) has been reported, but little information is available concerning how $\mathrm{Cd}$ affects nutrient acquisition and distribution within woody perennial plants. $\mathrm{Cd}$ provokes changes in both the physiological and morphological characteristics of plants, reducing growth and affecting their assimilatory capacity, water balance, and provoking structural changes (Lux et al., 2004; Wójcik et al., 2005) as well as disturbances of nutrient uptake and distribution (Sarwar et al., 2010).

Due to growing demands for raw materials such as paper, cellulose, charcoal and wood, plantings of exotic species such as eucalyptus have increased in Brazil. Their rapid growth, well-developed root systems and widespread distributions in Brazil give species such as Eucalyptus maculata Hook. and E. urophilla S. T. Blake (that are reportedly heavy metal tolerant) significant potential for use in restoration programs of contaminated soils (Soares et al., 2005).

In this context, the present study investigated Cdtolerance in E. camaldulenses as a promising species for Cd-reclamation programs, the physiological and anatomical features associated with $\mathrm{Cd}$ uptake and bioaccumulation, as well as the mineral nutrition of this species.

\section{Material and methods}

\subsection{Plant growth}

E. camaldulenses seeds were acquired from the Seed Commercial Production Area of Açailandia (Maranhão, Brazil) and germinated in Styrofoam trays in a thermostat-controlled and darkened chamber $(70 \%$ relative humidity, at $25^{\circ} \mathrm{C}$ ). Forty-five-day-old seedlings having similar sizes and weights were transferred 
to plastic beakers $\left(6 \mathrm{~m}^{-3}\right.$ capacity, four plants per beaker) containing Clark's nutrient solution $(2.53 \mathrm{mmol}$

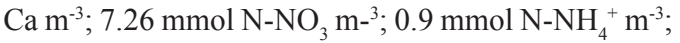
$1.80 \mathrm{mmol} \mathrm{K} \mathrm{m}^{-3} ; 0.7 \mathrm{mmol} \mathrm{Cl} \mathrm{m}^{-3} ; 0.07 \mathrm{mmol} \mathrm{P} \mathrm{m}^{-3}$; $0.6 \mathrm{mmol} \mathrm{Mg} \mathrm{m}^{-3} ; 0.5 \mathrm{mmol} \mathrm{S} \mathrm{m}^{-3} ; 7 \mathrm{mmol} \mathrm{Mn} \mathrm{m}^{-3}$; $19 \mathrm{mmol} \mathrm{B} \mathrm{m}^{-3} ; 2 \mathrm{mmol} \mathrm{Zn} \mathrm{m}{ }^{-3} ; 0.6 \mathrm{mmol} \mathrm{Mo} \mathrm{m}^{-3}$; $0.5 \mathrm{mmol} \mathrm{Cu} \mathrm{m}^{-3} ; 38 \mathrm{mmol} \mathrm{Fe} \mathrm{m}^{-3}$, Clark, 1975) and maintained under greenhouse conditions (temperature $15-31{ }^{\circ} \mathrm{C}$; average photosynthetic photon flux density $825 \mu \mathrm{mol} \mathrm{m} \mathrm{m}^{-2} \mathrm{~s}^{-1}$ ). After an additional growth period of 15 days, $\mathrm{Cd}$ was added ( $\mathrm{as}^{\mathrm{CdSO}}{ }_{4}$ ) at different concentrations $\left(0,15,25,45\right.$ and $\left.90 \mu \mathrm{mol} \mathrm{m}^{-3}\right)$ to the culture media of plants selected for their apparent vigor. The nutrient solutions were continuously aerated and renewed weekly. The $\mathrm{pH}$ of the medium was checked and adjusted on a daily basis to $5.5 \pm 0.1$. After 20 days of Cd-treatment, the plants were harvested and divided into root and shoot fractions, placed in paper bags and dried in an air circulation oven at $70{ }^{\circ} \mathrm{C}$ to a constant weight to determine biomass production.

\subsection{Chemical analyses}

Plant samples $(0.1 \mathrm{~g})$ were digested in $5 \mathrm{ml}$ of a strong acid solution $\left(\mathrm{HNO}_{3} / \mathrm{HClO}_{4}, 3: 1, \mathrm{v} \mathrm{v}^{-1}\right)$ (Silva, 1999) and their $\mathrm{Ca}, \mathrm{Cd}, \mathrm{Cu}, \mathrm{K}, \mathrm{Fe}, \mathrm{Mg}, \mathrm{Mn}$, and $\mathrm{Zn}$ concentrations were determined using flame atomic absorption spectrometry (Perkin-Elmer AAnalyst 400, Norwalk, CT). Nitrogen was determined by titration after Kjeldahl digestion; sulfur by turbidimetry (Malavolta et al., 1989); and phosphorous concentrations in solution were measured by colorimetry following the phosphorus-molybdate method.

The mineral contents ( $\mathrm{Cd}$ and nutrients) of shoots, roots, and whole plants were calculated considering dry weight (DW) productions (element concentration $\mathrm{x}$ dry matter production). The primary transport index (PTI) was calculated as the ratio of mineral contents in the shoots to those of the roots (Moral et al., 1994). The Cd-critical dose solution values of $\mathrm{CDS}_{10}$ and $\mathrm{CDS}_{50}$ (Cd-concentrations of solutions that promoted decreases of $10 \%$ and $50 \%$ in plant yields respectively) and Cd-toxicity levels (TCL: Cd-concentrations in shoots that promoted $10 \%$ decreases in shoot yields) were assessed. To study $\mathrm{Cd}$ uptake and bioconcentration behavior, the following indices were used: bioconcentration factor (BCF), calculated by dividing the Cd-concentration in plant tissues ( $\mathrm{mg} \mathrm{g}^{-1} \mathrm{DW}$ ) at harvest by the metal concentration in the solution (Sharma and Agrawal, 2006); total accumulation rate (TAR, mg plant ${ }^{-1} \mathrm{~d}^{-1}$ ) was determined following Zhu et al. (1999) calculated by (root $\mathrm{Cd}$ content + shoot $\mathrm{Cd}$ content)/(total dry matter $\mathrm{x} T$ ), where $\mathrm{T}$ is the experimental period (20 days).

\subsection{Light microscopy}

Anatomical analyses were performed at the end of the experimental period (20 days after initiating the Cdtreatment) to verify possible tolerance features induced by $\mathrm{Cd}$ that allowed plants to survive. Root samples were collected and fixed for $48 \mathrm{hrs}$ in Karnovsky's fixative solution (2.5\% glutaraldehyde and $2.5 \%$ paraformaldehyde), dehydrated in a graded ethanol series, and included in butanol/plastic resin (Historesin, Laica). Semi-thin sections (5 to $8 \mathrm{~mm}$ thick) were prepared using a Jung AG rotary microtome and stained with toluidine blue (equal volumes of $0.3 \%$ of basic toluidine and $1 \%$ sodium tetraborate). All slides were examined and photographed using a Ken-a-Vision TT18 light microscope equipped with a Canon Power Shot A620 digital camera. Measurements of the anatomical characteristics were made using Sigma Scan software. The items assessed in the root system included: thick- 
ness of the epidermis and endodermis, and the numbers and diameters of the tracheary elements. The evaluation of $\mathrm{Cd}$ effects on hydraulic limitations considered the relationship between the diameters and numbers of root tracheary elements (Carlquist vulnerability index - CVI) according to Carlquist (1975) (CVI = vessel diameter/vessel frequency). A minimum of five samples were tested for each $\mathrm{Cd}$ treatment.

\subsection{Statistical analyses}

The results are expressed as the averages of five replicates. The data were statistically evaluated using analysis of variance run on the SAS software program (SAS Institute Ins., 1996). Regression and correlation analyses were also performed to test for relationships between the variables. The percentage data relating to the mineral element contents of Cd-treated plants were divided by the concentrations of the same min- eral in the control plants and arc-sine transformed before being submitted to Scott-Knott testing at a 5\% probability level.

\section{Results}

\subsection{Plant growth and visual symptoms}

Dry weight (DW) production was negatively affected by Cd concentrations (Figure 1). Cd had inhibiting effects on growth up to concentrations of $45 \mu \mathrm{mol} \mathrm{m}{ }^{-3}$ $\mathrm{Cd}$; at higher concentrations, dry biomass production of both shoots and roots showed only slight changes. The Cd-critical dose solution $\left(\mathrm{Cd}-\mathrm{CDS}_{10}\right)$ concentration for shoots was $6.6 \mu \mathrm{mol} \mathrm{m} \mathrm{m}^{-3}$, and $5.5 \mu \mathrm{mol} \mathrm{m}$ for roots. $\mathrm{CDS}_{50}$ was $71.24 \mu \mathrm{mol} \mathrm{m}{ }^{-3}$ for roots; $50 \%$ of shoot-yield reductions were not observed. The $\mathrm{Cd}$ toxicity level (TCL) in the shoot was approximately $32 \mathrm{mg} \mathrm{g}^{-1} \mathrm{DW}\left(y=1.2567-0.0042 x ; r^{2}=0.72\right)$.

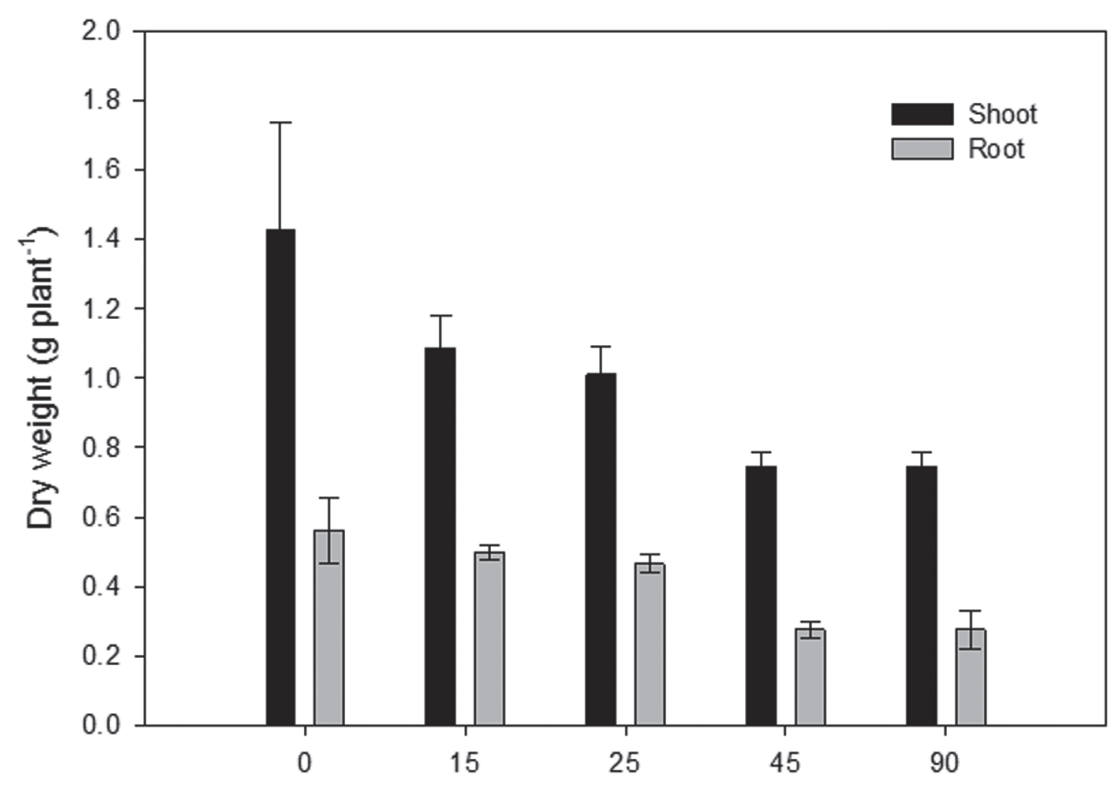

Figure 1. Shoot and root dry weight (DW) production of E. camaldulenses plants cultivated in nutritive solution

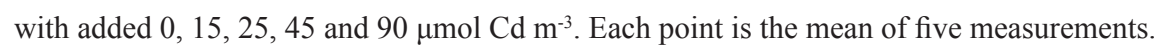


Plants growing in the solutions with the highest $\mathrm{Cd}$ concentrations showed symptoms of Cd phytotoxicity; at the end of the experimental period the plants appeared wilted and had yellowed leaves as well as blackened and thickened roots.

\subsection{Cadmium content, uptake, and bioaccumulation}

Except in the controls, the Cd contents of roots were higher than those of the shoots (Table 1). The greatest increases in $\mathrm{Cd}$ content were observed in plants growing in the highest $\mathrm{Cd}$ concentrations (Table 1). Although plants grown in $45 \mu \mathrm{mol} \mathrm{m} \mathrm{m}^{-3} \mathrm{Cd}$ showed significant increases in both their root $(+450 \%)$ and shoot $(+350 \%)$ Cd-contents as compared to the control, when compared to the others Cd treatments these plants demonstrated the lowest increases in Cd contents of their tissues $(p<0.05)$ (Table 2). The increment on total content of Cd per plant over the control did not differ in plants of treatments ranging from 15 to $25 \mathrm{mmol} \mathrm{m}^{-3} \mathrm{Cd}$ and was lowest in $45 \mathrm{mmol} \mathrm{m}^{-3} \mathrm{Cd}$ $(p<0.05)$ (Table 2).

Table 1. Shoot, root, and total plant Cd content, primary transport index (PTI), shoot and root bioconcentration factors (BCF), and total accumulation rate (TAR), in Eucalyptus camaldulenses plants cultivated in nutritive

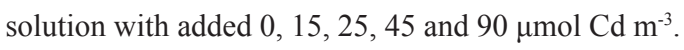

\begin{tabular}{lccccc}
\hline & \multicolumn{5}{c}{ Cd concentrations $\left(\boldsymbol{\mu} \mathbf{m o l ~ m}^{-3}\right)$} \\
\cline { 2 - 6 } & $\mathbf{0}$ & $\mathbf{1 5}$ & $\mathbf{2 5}$ & $\mathbf{4 5}$ & $\mathbf{9 0}$ \\
\hline Shoot Cd-content $\left(\mathrm{mg} \mathrm{shoot}^{-1}\right)$ & $14.0 \mathrm{~d}$ & $77.6 \mathrm{~b}$ & $84.4 \mathrm{~b}$ & $63.2 \mathrm{c}$ & $126.0 \mathrm{a}$ \\
Root Cd-content $\left(\mathrm{mg} \mathrm{root}^{-1}\right)$ & $0.6 \mathrm{c}$ & $353.8 \mathrm{~b}$ & $381.5 \mathrm{~b}$ & $250.9 \mathrm{~b}$ & $530.9 \mathrm{a}$ \\
Total Cd-content $\left(\mathrm{mg} \mathrm{plant}^{-1}\right)$ & $14.6 \mathrm{~d}$ & $431.4 \mathrm{~b}$ & $465.9 \mathrm{~b}$ & $314.1 \mathrm{c}$ & $656.9 \mathrm{a}$ \\
Cd PTI & $24.8 \mathrm{a}$ & $0.2 \mathrm{~b}$ & $0.2 \mathrm{~b}$ & $0.25 \mathrm{~b}$ & $0.3 \mathrm{~b}$ \\
Shoot BCF & $*$ & $0.4 \mathrm{a}$ & $0.3 \mathrm{~b}$ & $0.1 \mathrm{c}$ & $0.2 \mathrm{c}$ \\
Root BCF & $*$ & $0.4 \mathrm{a}$ & $0.3 \mathrm{~b}$ & $0.1 \mathrm{c}$ & $0.2 \mathrm{c}$ \\
TAR $\left(\mu \mathrm{g} \mathrm{d}^{-1}\right)$ & $0.4 \mathrm{c}$ & $13.6 \mathrm{~b}$ & $15.8 \mathrm{~b}$ & $15.3 \mathrm{~b}$ & $31.8 \mathrm{a}$ \\
\hline
\end{tabular}

Different letters within the same line indicate significant differences after arc-sine transformation (Scott-Knott, $p<0.05) .{ }^{*}$ Not applicable

Control plants had low Cd contents in their tissues, but with higher $\mathrm{Cd}$ contents in the shoots than the roots (Table 1). The Cd primary transport index (PTI) did not differ among the Cd-treated plants, and was higher in control plants (Table 1). The bioconcentration factors (BCF) of both shoots and roots decreased up to $45 \mu \mathrm{mol} \mathrm{Cd} \mathrm{m}^{-3}$. Total accumulation rate (TAR) was higher in the presence of $\mathrm{Cd}$, and increased in plants exposed to highest $\mathrm{Cd}$ concentrations (Table 1).

\subsection{Nutrient contents}

Shoot, root, and total plant mineral element contents are shown in Table 2. The ratios of the element contents in each $\mathrm{Cd}$ treatment in relation to the control were calculated (in percentage) for shoots, roots, and total plants (Table 1). 
Table 2. Shoot, root, and total plant content of mineral elements in Eucalyptus camaldulenses plants cultivated in

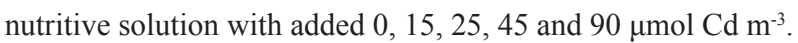

\begin{tabular}{|c|c|c|c|c|c|}
\hline & \multicolumn{5}{|c|}{ Cd levels $\left.(\mu \mathrm{mol} \mathrm{m})^{-3}\right)$} \\
\hline & $\mathbf{0}$ & 15 & 25 & 45 & 90 \\
\hline \multicolumn{6}{|l|}{ Shoot } \\
\hline $\mathrm{N}\left(\mathrm{mg} \mathrm{shoot}^{-1}\right)$ & 58.7 & $-34 d$ & $-54 c$ & $-65 b$ & $-72 a$ \\
\hline $\mathrm{P}\left(\mathrm{mg} \mathrm{shoot}^{-1}\right)$ & 4.5 & $+6 \mathrm{a}$ & $-32 b$ & $-48 c$ & $-45 d$ \\
\hline $\mathrm{K}\left(\mathrm{mg} \operatorname{shoot}^{-1}\right)$ & 21.8 & $-38 \mathrm{a}$ & $-46 b$ & $-65 c$ & $-51 c$ \\
\hline $\mathrm{Ca}\left(\mathrm{mg} \mathrm{shoot}^{-1}\right)$ & 15.5 & $+2 \mathrm{a}$ & $-6 b$ & $-35 c$ & $-26 b$ \\
\hline $\operatorname{Mg}\left(\right.$ mg shoot $\left.^{-1}\right)$ & 3.6 & $-14 a$ & $-24 a$ & $-38 b$ & $-37 b$ \\
\hline $\mathrm{S}\left(\mathrm{mg}\right.$ shoot $\left.^{-1}\right)$ & 1.0 & $+66 \mathrm{a}$ & $+71 \mathrm{~b}$ & $+11 \mathrm{c}$ & $-61 d$ \\
\hline $\mathrm{Cd}\left(\mu \mathrm{g}\right.$ shoot $\left.^{-1}\right)$ & 14.0 & $+453 b$ & $+501 \mathrm{~b}$ & $+350 \mathrm{c}$ & $+798 \mathrm{a}$ \\
\hline $\mathrm{Fe}\left(\mu \mathrm{g} \mathrm{shoot}^{-1}\right)$ & 348.5 & $-68 \mathrm{a}$ & $-76 b$ & $-81 c$ & $-82 c$ \\
\hline $\mathrm{Zn}\left(\mu \mathrm{g} \mathrm{shoot}^{-1}\right)$ & 79.9 & $-45 a$ & $-61 b$ & $-66 b$ & $-73 b$ \\
\hline $\mathrm{Cu}\left(\mu \mathrm{g} \mathrm{shoot}^{-1}\right)$ & 17.0 & $-71 \mathrm{a}$ & $-85 b$ & $-85 b$ & $-86 c$ \\
\hline $\operatorname{Mn}\left(\mu \mathrm{g} \mathrm{shoot}^{-1}\right)$ & 217.3 & $-26 a$ & $-47 b$ & $-57 b$ & $-58 b$ \\
\hline \multicolumn{6}{|l|}{ Roots } \\
\hline $\mathrm{N}\left(\mathrm{mg} \operatorname{root}^{-1}\right)$ & 14.0 & $-11.2 \mathrm{a}$ & $-7.0 \mathrm{a}$ & $-51.7 b$ & $-49.8 b$ \\
\hline $\mathrm{P}\left(\mathrm{mg} \mathrm{root}^{-1}\right)$ & 1.0 & $+34.3 b$ & $+116.3 \mathrm{a}$ & $+27.9 \mathrm{~b}$ & $+21.9 \mathrm{~b}$ \\
\hline $\mathrm{K}\left(\mathrm{mg} \operatorname{root}^{-1}\right)$ & 12.9 & $-12.1 \mathrm{a}$ & $-25.7 b$ & $-53.7 \mathrm{c}$ & $-60.0 c$ \\
\hline $\mathrm{Ca}\left(\mathrm{mg} \mathrm{root}^{-1}\right)$ & 4.8 & $-8.7 \mathrm{a}$ & $-6.8 \mathrm{a}$ & $-44.5 b$ & $-47.4 b$ \\
\hline $\operatorname{Mg}\left(\mathrm{mg} \mathrm{root}^{-1}\right)$ & 1.5 & $-14.8 b$ & $+10.3 \mathrm{a}$ & $-45.1 \mathrm{c}$ & $-39.4 c$ \\
\hline $\mathrm{S}\left(\mathrm{mg} \operatorname{root}^{-1}\right)$ & 1.0 & $+62.0 \mathrm{a}$ & $+32.7 \mathrm{a}$ & $-27.3 b$ & $-51.6 b$ \\
\hline $\mathrm{Cd}\left(\mu \mathrm{g} \operatorname{root}^{-1}\right)$ & 0.6 & $+59972.4 \mathrm{~b}$ & $+644670.7 \mathrm{~b}$ & $+42496.4 \mathrm{~b}$ & $+90023.5 \mathrm{a}$ \\
\hline $\mathrm{Fe}\left(\mathrm{mg} \mathrm{root}^{-1}\right)$ & 1.0 & $+8.6 \mathrm{~b}$ & $+73.6 \mathrm{a}$ & $+11.8 b$ & $-18.3 b$ \\
\hline $\mathrm{Zn}\left(\mu \mathrm{g} \operatorname{root}^{-1}\right)$ & 75.5 & $-15.3 \mathrm{a}$ & $-22.4 \mathrm{a}$ & $+49.4 \mathrm{~b}$ & $-45.1 b$ \\
\hline $\mathrm{Cu}\left(\mu \mathrm{g} \operatorname{rot}^{-1}\right)$ & 15.4 & $+53.5 \mathrm{~b}$ & $+116.0 \mathrm{a}$ & $+25.9 \mathrm{c}$ & $+30.4 \mathrm{c}$ \\
\hline $\operatorname{Mn}\left(\mu \mathrm{g}_{\operatorname{root}^{-1}}\right)$ & 29.75 & $-72.44 b$ & $-65.79 a$ & $-79.16 b$ & $-74.3 b$ \\
\hline \multicolumn{6}{|l|}{ Total } \\
\hline $\mathrm{N}\left(\mathrm{mg} \mathrm{plant}^{-1}\right)$ & 72.7 & $-28.6 a$ & $-45.0 b$ & $-62.5 c$ & $-68.4 d$ \\
\hline $\mathrm{P}\left(\mathrm{mg} \mathrm{plant}^{-1}\right)$ & 5.5 & $+11.6 \mathrm{a}$ & $-4.7 b$ & $-34.4 c$ & $-32.6 c$ \\
\hline $\mathrm{K}\left(\mathrm{mg}\right.$ plant $\left.^{-1}\right)$ & 34.6 & $-28.8 \mathrm{a}$ & $-39.0 b$ & $-60.9 c$ & $-54.4 c$ \\
\hline $\mathrm{Ca}\left(\mathrm{mg} \mathrm{plant}^{-1}\right)$ & 20.3 & $-0.3 \mathrm{a}$ & $-6.8 b$ & $-37.8 c$ & $-31.7 c$ \\
\hline $\operatorname{Mg}\left(\right.$ mg plant $\left.^{-1}\right)$ & 5.1 & $-14.5 \mathrm{a}$ & $-14.7 \mathrm{a}$ & $-40.7 b$ & $-38.7 b$ \\
\hline $\mathrm{S}\left(\mathrm{mg}\right.$ plant $\left.^{-1}\right)$ & 2.0 & $+64.8 \mathrm{a}$ & $+52.9 \mathrm{a}$ & $-7.1 b$ & $-56.9 b$ \\
\hline $\mathrm{Cd}\left(\mu \mathrm{g}\right.$ plant $\left.^{-1}\right)$ & 14.6 & $+2852.1 \mathrm{~b}$ & $+3088.0 \mathrm{~b}$ & $+2049.7 \mathrm{c}$ & $+4395.0 \mathrm{a}$ \\
\hline $\mathrm{Fe}\left(\mathrm{mg}\right.$ plant $\left.^{-1}\right)$ & 1.4 & $-10.8 \mathrm{a}$ & $+35.3 \mathrm{a}$ & $-11.8 b$ & $-34.7 \mathrm{c}$ \\
\hline $\mathrm{Zn}\left(\mu \mathrm{g}\right.$ plant $\left.^{-1}\right)$ & 155.4 & $-30.8 \mathrm{a}$ & $-42.6 b$ & $-58.0 \mathrm{~b}$ & $-59.5 c$ \\
\hline $\mathrm{Cu}\left(\mu\right.$ g plant $\left.^{-1}\right)$ & 32.4 & $-12.0 b$ & $+10.5 \mathrm{a}$ & $-32.6 c$ & $-31.0 \mathrm{c}$ \\
\hline $\operatorname{Mn}\left(\mu \mathrm{g}\right.$ plant $\left.^{-1}\right)$ & 247.0 & $-32.0 \mathrm{a}$ & $-49.8 b$ & $-59.8 c$ & $-60.7 c$ \\
\hline
\end{tabular}

Data for treatments with $15,25,45$ and $90 \mu \mathrm{mol} \mathrm{Cd} \mathrm{m}{ }^{-3}$ represent the percent changes (+, increase; -, decrease) in relation to the control. Different letters within the same line indicate significant differences after arc-sine transformation (Scott-Knott, $p<0.05$ ). 
Decreased shoot contents of N, P, K, Ca, Mg, Fe, Zn, $\mathrm{Cu}$, and $\mathrm{Mn}$ were observed in Cd-treated plants. Root contents of N, K, Ca, Zn, and Mn decreased and P and $\mathrm{Cu}$ contents increased in the presence of $\mathrm{Cd}$. Root $\mathrm{Mg}$ content increased at $25 \mu \mathrm{mol} \mathrm{m}{ }^{-3} \mathrm{Cd}$ and decreased in relation to the control in the other $\mathrm{Cd}$ treatments; $\mathrm{S}$ content increased up to $25 \mu \mathrm{mol} \mathrm{m}{ }^{-3} \mathrm{Cd}$ and decreased at higher $\mathrm{Cd}$ concentrations. Increasing root $\mathrm{Fe}$ contents at $\mathrm{Cd}$ treatments up to $45 \mu \mathrm{mol} \mathrm{m} \mathrm{m}^{-3}$ were followed by decreases in plants exposed to the highest $\mathrm{Cd}$ treatment.
The primary transport index of each nutrient is shown in Table 3. The PTI of N, P, Zn, and Cu were reduced in relation to the control, while that of $\mathrm{Mn}$ increased in the presence of Cd. The PTI of K decreased at $\mathrm{Cd}$ concentrations up to $45 \mu \mathrm{mol} \mathrm{m} \mathrm{m}^{-3}$, and increased at the highest $\mathrm{Cd}$ concentrations; the inverse was seen with S. The PTI of Ca increased above control levels

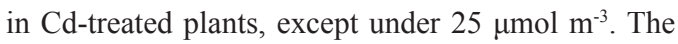
PTI of $\mathrm{Mg}$ decreased at 15 and $25 \mu \mathrm{mol} \mathrm{m} \mathrm{m}^{-3} \mathrm{Cd}$, and increased at higher $\mathrm{Cd}$ concentrations.

Table 3. Primary transport index (PTI) of mineral nutrients in Eucalyptus camaldulenses plants cultivated in

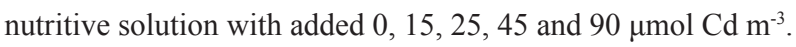

\begin{tabular}{lccccc}
\hline & \multicolumn{5}{c}{ Cd levels $\left(\boldsymbol{\mu m o l ~ \mathbf { ~ m } ^ { - 3 } )}\right.$} \\
\cline { 2 - 6 } & $\mathbf{0}$ & $\mathbf{1 5}$ & $\mathbf{2 5}$ & $\mathbf{4 5}$ & $\mathbf{9 0}$ \\
\hline $\mathbf{N}$ & 4.31 & $-32.7 \mathrm{~b}$ & $-52.0 \mathrm{~d}$ & $-27.4 \mathrm{a}$ & $-45.9 \mathrm{c}$ \\
$\mathbf{P}$ & 4.42 & $-20.3 \mathrm{a}$ & $-68.8 \mathrm{~b}$ & $-60.0 \mathrm{~b}$ & $-53.9 \mathrm{~b}$ \\
$\mathbf{K}$ & 1.73 & $-31.0 \mathrm{~b}$ & $-30.2 \mathrm{~b}$ & $-25.9 \mathrm{~b}$ & $+24.4 \mathrm{a}$ \\
$\mathbf{C a}$ & 3,35 & $+10.2 \mathrm{~b}$ & $-1.8 \mathrm{~b}$ & $+12.4 \mathrm{~b}$ & $+43.2 \mathrm{a}$ \\
$\mathbf{M g}$ & 2.55 & -0.3 & -33.1 & +10.9 & $+9.9 \mathrm{~ns}$ \\
$\mathbf{S}$ & 1.08 & $+0.3 \mathrm{c}$ & $+27.9 \mathrm{~b}$ & $+62.0 \mathrm{a}$ & $-1.0 \mathrm{c}$ \\
$\mathbf{C d}$ & 24.84 & -99.1 & -99.1 & -99.0 & $-98.9 \mathrm{~ns}$ \\
$\mathbf{F e}$ & 0.35 & -70.6 & -86.6 & -83.8 & $-78.8 \mathrm{~ns}$ \\
$\mathbf{Z n}$ & 1.07 & $-36.3 \mathrm{a}$ & $-50.3 \mathrm{~b}$ & $-33.3 \mathrm{~b}$ & $-50.2 \mathrm{~b}$ \\
$\mathbf{C u}$ & 1.17 & $-82.8 \mathrm{a}$ & $-93.6 \mathrm{~b}$ & $-89.2 \mathrm{~b}$ & $-90.2 \mathrm{c}$ \\
$\mathbf{M n}$ & 7.55 & $+159.8 \mathrm{~b}$ & $+52.0 \mathrm{a}$ & $+98.6 \mathrm{~b}$ & $+57.0 \mathrm{~b}$ \\
\hline
\end{tabular}

Data for treatments with 15, 25, 45 and $90 \mu \mathrm{mol} \mathrm{Cd} \mathrm{m}^{-3}$ represent the percent changes (+, increase; -, decrease) in relation to the control. Different letters within the same line indicate significant differences after arc-sine transformation (Scott-Knott, $p<0.05$. ns - not significant).

\subsection{Anatomical features}

Quantitative anatomical changes were observed in root tissues in response to $\mathrm{Cd}$ exposure. Root epidermal and endodermal thicknesses increased as $\mathrm{Cd}$ treatment doses increased (Figure 2A). Moreover, these tissues showed thickened cell walls. The relationships between endodermal and epidermal thicknesses and shoot and root $\mathrm{Cd}$ contents are presented in Figure 2B. This data suggests a possible role of the endodermis in limiting $\mathrm{Cd}$ translocation to shoots at Cd-exposure levels above $\sim 19 \mu \mathrm{mol} \mathrm{m} \mathrm{m}^{-3}$, as well as an additional epidermal contribution observed principally at Cd-exposure levels above $\sim 49$ $\mu \mathrm{mol} \mathrm{m}{ }^{-3}$; above these exposure levels, the slope of the curve relating shoot $\mathrm{Cd}$ content and $\mathrm{Cd}$ treatments deceased (Figure 2a), further corroborating this hypothesis. The vascular cylinders of Cd-treat- 
ed roots showed small xylem vessels with thickened cell walls, but they did not differ in numbers from the controls $(P>0.05)$. The Carlquist vulnerability index (CVI) therefore decreased as $\mathrm{Cd}$ treatment doses increased (Figure 3). An inverse relationship between endodermal thickness and CVI was observed on exposure to increasing $\mathrm{Cd}$ concentrations (Figure 3).
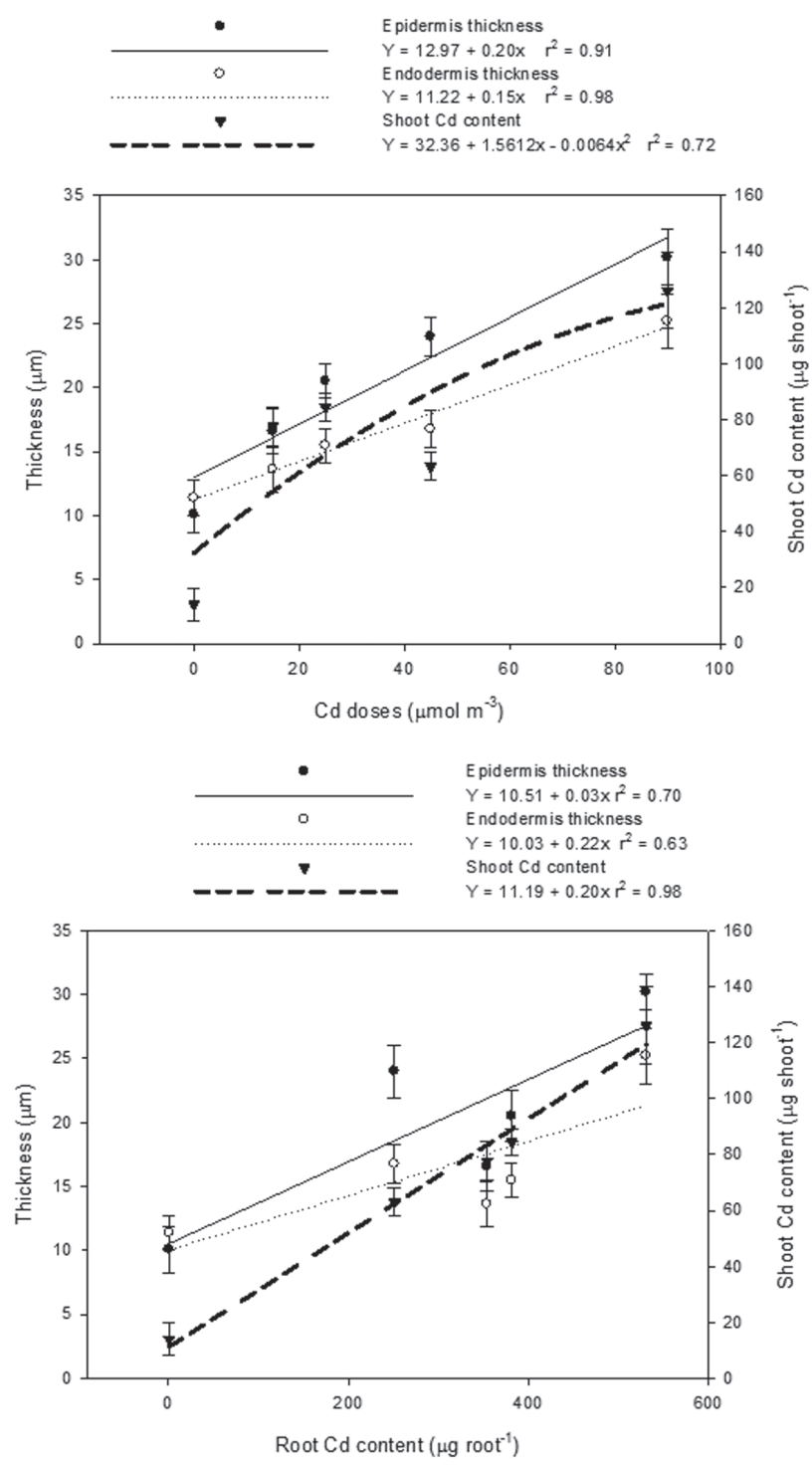

Figure 2. (A) Relationships between epidermal and endodermal thicknesses, shoot $\mathrm{Cd}$ contents, root $\mathrm{Cd}$ contents, and substrate $\mathrm{Cd}$ concentrations; (B) relationships between epidermal and endodermal thicknesses, shoot $\mathrm{Cd}$ contents, and root $\mathrm{Cd}$ content. Each point is the mean of five measurements. 


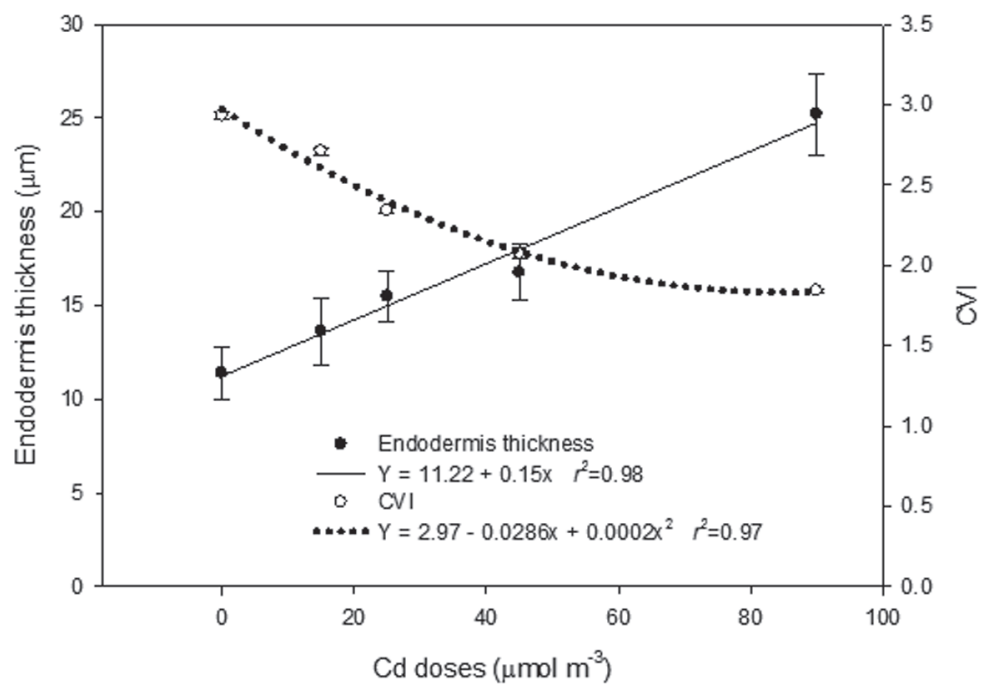

Figure 3. Relationships between endodermal thickness/Carlquist vulnerability index (CVI) and substrate Cd concentrations in Eucalyptus camaldulenses plants cultivated in nutritive solution with added 0, 15, 25, 45 and $90 \mu \mathrm{mol} \mathrm{Cd} \mathrm{m}{ }^{-3}$.

\section{Discussion}

Our results demonstrated that $\mathrm{Cd}$ exposure provoked deleterious effects on E. camaldulenses plants, including growth reductions and visual symptoms of toxicity. Similar phytotoxic symptoms were reported by Soares et al. (2005) in E. maculata and E. urophilla grown in nutrient solutions with increasing $\mathrm{Cd}$ concentrations (mainly at treatments of $90 \mu \mathrm{mol} \mathrm{m} \mathrm{m}^{-3}$ $\mathrm{Cd}$ and higher). These symptoms may have been associated with multiple deficiencies of several nutrients essential for the formation, expansion, and operation of chloroplasts and with Cd-phytotoxic effects on the extensibility or synthesis of cell wall material (Barceló et al., 1990).

Cd phytotoxicity was noticeable in the roots, which showed greater decreases in biomass production than the shoots (Figure 1). In addition to coming directly in contact with substrate $\mathrm{Cd}$, roots showed higher $\mathrm{Cd}$ contents than shoots (Table 1) and were presumably more subject to toxic heavy metal effects. The $\mathrm{CDS}_{10}$ of E. camaldulenses shoots was higher $\left(6.6 \mu \mathrm{mol} \mathrm{m}{ }^{-3}\right)$ than that reported by Soares et

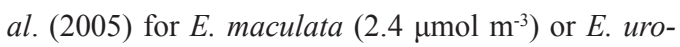
phylla $\left(1.5 \mathrm{mmol} \mathrm{m}^{-3}\right)$. Additionally, $50 \%$ reductions in shoot yields in these species were seen at 63.1 and $54.4 \mu \mathrm{mol} \mathrm{m}{ }^{-3}$, which was not observed in the present study. However, while the $\mathrm{CDS}_{10}$ of the roots (5.5 $\mu \mathrm{mol} \mathrm{m} \mathrm{m}^{-3}$ ) was lower in E. camaldulenses than in $E$ maculata $\left(\mathrm{CDS}_{10}=9.0 \mu \mathrm{mol} \mathrm{m}-3\right)$ and E. urophylla $\left(\mathrm{CDS}_{10}=6.4\right)$, its $\operatorname{CDS}_{50}\left(71.24 \mu \mathrm{mol} \mathrm{m} \mathrm{m}^{-3}\right)$ was higher than either species $\left(\mathrm{CDS}_{50}=62.8 \mu \mathrm{mol} \mathrm{m}{ }^{-3}\right.$ and $\mathrm{CDS}_{50}$ $=44.7 \mu \mathrm{mol} \mathrm{m} \mathrm{m}^{-3}$ respectively), demonstrating the wide variations in Cd-responses in different species and plant tissues. Likewise, Paiva et al. (2000) found higher shoot $\mathrm{CDS}_{10}$ in the native Brazilian species $\mathrm{Ce}$ drela fissilis Vell. and Tabebuia impetiginosa (Mart.

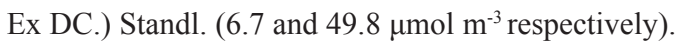
According to Marchial et al. (1996), the differences in the behaviors of different species maybe due to ge- 
netic or physiological features such as the existence of blockers in roots promoting $\mathrm{Cd}$ allocation to the cell walls and apoplastic structures. The above-mentioned concentrations of $\mathrm{Cd}$ that inhibited growth exceeded the concentrations of soluble $\mathrm{Cd}$ found in the vast majority of contaminated soils.

In addition to the relatively small decreases in shoot DW production, the Cd-tolerance of E. camaldulenses could be seen in the elevated TCL of the species (32 $\left.\mathrm{mg} \mathrm{g}^{-1} \mathrm{DW}\right)$. The TCL of E. camaldulenses was also higher than that reported by Soares et al. (2005) for E. maculata and E. urophylla (14.5 and $10.8 \mathrm{mg} \mathrm{g}^{-1} \mathrm{DW}$ respectively). In species that are highly sensitive to this heavy metal, TCL ranged from 5 to $10 \mathrm{mg} \mathrm{g}^{-1} \mathrm{Cd}$ (Macnicol and Beckett, 1985), supporting the observed Cd-tolerance of E. camaldulenses. When plants are grown on contaminated substrates, $\mathrm{Cd}$ is most likely to be concentrated in the roots (Kabatta-Pendias, 2000), and when the Cd concentration in the growth medium increases, the concentrations of this metal in the roots can exceed its shoot content by more than a factor of 100 (Kabatta-Pendias, 2000). Although root growth was negatively affected in $E$. camaldulenses, Cd-TAR was not (Table 1). TAR is a measure of heavy metal uptake by plants and this index has been widely used in bioaccumulation studies (Zhu et al., 1999). The highest Cd-TAR was seen in plants grown at the highest media $\mathrm{Cd}$ concentrations - with the highest Cd contents and lowest Cd-PTIs - demonstrating a positive relationship between $\mathrm{Cd}$ media concentrations and the uptake and root retention capacities of $E$. camaldulenses.

One of the mechanisms associated with heavy metal tolerance in plants involves decreasing metal translocation to the shoots (Shi and Cai, 2009), which was seen in the present study. A mean reduction of $99 \%$ was seen in the Cd-PTI of Cd-treated plants, showing the preferential retention of this heavy metal in the roots (Table 3). By employing this strategy plants can avoid negative growth effects by reducing heavy metal interference in their photosynthetic processes (including chlorophyll synthesis, chloroplast organization, and PSII activity) (Sandalio et al., 2001).

The restrictions of $\mathrm{Cd}$ transport to shoots can also be related to morphological and anatomical responses of the plants, as was seen in the roots of Cd-treated plants. Epidermal and endodermal thickening, decreases in xylem vessel diameters, and CVI are all related to Cd-tolerance in E. camalduenses. Epidermal thickening increases negative charge accumulation and biological filtering of metal ions (Gomes et al., 2011a). Additionally, increasing endodermal and cell wall thicknesses may also reflect heavy metal tolerance mechanisms (Gomes et al., 2011a). Cell walls have been found to be one of the most important sites of heavy metal allocation (Wójcik et al., 2005) and the endodermis is one the most important accumulation locations in roots (Lux et al., 2004; Wójcik et al., 2005). As such, cell wall thickening in the root endodermis provides greater areas for $\mathrm{Cd}$ retention and decreases its translocation to the shoot (Gomes et al., 2011a).

In terms of physiological processes, $\mathrm{Cd}$ appears to interfere with the plant water status (Barceló et al., 1990). As under salt stress, the development of apoplastic barriers (such as the endodermis) have been correlated with increasing resistance to the radial flow of water and solutes in roots, resulting in the reduced ion uptakes (i.e. $\mathrm{Na}^{+}$) into shoots - and better survival under subsequent acute stress (Krishnamurthy et al., 2011). As a result of decreased water flow and water status, plants may experience interrupted water conductivity in their xylem vessels (Dickson, 2000). As such, morphological changes in the conductive system of plants may represent an additional tolerance mechanism to deal with heavy metal exposure (Lux et al., 2004; Gomes et al., 2011a), and the inverse relationship between endodermal thickness and CVI appears to support this view. While endodermal thick- 
ness will lead to reduced water flow into the xylem vessels, the reductions in vessel diameters (and so CVI) will maintain water conductivity. Moreover, the reductions of tracheal element diameters were related to the increased thicknesses of their cell walls. In addition to ensuring water conductivity (Wójcik et al., 2005), the availability of thicker cell walls increases Cd-binding and limits heavy metal translocation to the shoots. Decreases in xylem diameters (as well as their increased cell wall thicknesses) in response to heavy metal exposure was reported in brachiaria grass and willows by Gomes et al. (2011a,b). These morphological alterations are related to heavy metal-induced imbalances in phytohormones (Barceló et al., 1990).

$\mathrm{BAF} / \mathrm{BCF}$ is more important than shoot concentrations per se when considering the phytoremediation potential of a given species (Zhao et al., 2003). The $\mathrm{BAC} / \mathrm{BCF}$ is typically lower than 1 in metalexcluder species, as seen in the present study (Table 1). The tendency towards decreasing $\mathrm{BAC} / \mathrm{BCF}$ as substrate metal concentrations increase has been reported in some studies (Zhao et al., 2003), indicating a diminishing efficiency of metal accumulation with increasing metal availability (Zhao et al., 2003). According to Pence et al. (2000), this decrease may be due to the saturation of metal uptake and/or root to shoot transport when internal metal concentrations are high. The lack of any difference between the BCFs

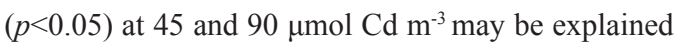
by the higher uptake of $\mathrm{Cd}$ by plants exposed to 90 mmol $\mathrm{Cd} \mathrm{m}^{-3}$ but the absence of any difference between their PTIs. This data suggests that Cd-uptake was not restricted or saturated in E. camaldulenses at substrate concentrations up to $90 \mu \mathrm{mol} \mathrm{Cd} \mathrm{m}^{-3}$, which supports its use in phytoremediation programs.

A plant's ability to survive in a stressful environment is correlated with its nutritional status, which can be affected by Cd uptake. Cd-induced changes in nutrient contents of eucalyptus species were reported by Soares et al. (2005). However, in contrast to the more common practice of evaluating nutrient levels, we evaluated the nutrient contents of the plants and, to assess the Cd effects, compared these values to the controls (Table 3) - thus avoiding dilution effects due to plant growth.

The deleterious effects of $\mathrm{Cd}$ on mineral absorption have been attributed to alterations in transpiration rates (Chaffei et al., 2004), and growth reductions in roots will likewise directly contribute to reduced mineral uptakes. Changes in $\mathrm{N}$ metabolism in Cd-stressed plants are similar to the changes observed during senescence (Masclaux et al., 2000), as was confirmed by the visual symptoms of $E$. camaldulenses leaves. Decreased nitrate reductase and nitrite reductase activities reduce nitrate assimilation by plants (Chaffei et al., 2004), and decrease photosynthetic rates and the chlorophyll contents of plants (Hernandez et al., 1997; Campbell, 1999). Nitrogen translocation from leaves to roots was seen in Cd-treated plants (Chaffei et al., 2004), and a positive correlation was observed between root $\mathrm{Cd}$ and $\mathrm{N}$ contents in 15 and $90 \mu \mathrm{mol}$ $\mathrm{Cd} \mathrm{m}^{-3}$ substrate concentrations $(r=0.958$ and $r=0.967$ respectively, $P=0.05$ ). According to these authors, this strategy may preserve roots as a nutritional safeguard organ to ensure future recovery, and also explain the lower N-PTI seen in Cd-treated plants.

Although $\mathrm{N}$ and $\mathrm{P}$ contents decreased in Cd-treated plants (as reported by Paiva et al., 2000; Soares et al., 2005), the contents of these elements remain higher in shoots than in roots. $\mathrm{N}$ is an important component of many structural, genetic, and metabolic compounds (Hassan et al., 2005) and $\mathrm{P}$ is indispensable for energy transfer and protein metabolism. The maintenance of these elements in shoots may contribute to Cd-tolerance and result in biomass production and the lessening of the deleterious effects of this element on shoot biomass. At the highest $\mathrm{Cd}$ concentrations, positive correlations were observed between shoot $\mathrm{N}$ 
content and biomass production $(r=0.955, P=0.01)$ as well as $\mathrm{Cd}$ and N/P content ( $r=0.916$ and $r=0.931$ respectively, $P=0.05$ ). Balanced nutrient distributions are important under environmental stress. The PTI of both $\mathrm{N}$ and $\mathrm{P}$ decreased in the presence of $\mathrm{Cd}$, showing a tendency of their retention in roots where $\mathrm{Cd}$ content was becoming higher, and a positive correlation was observed between the $\mathrm{N}$ and $\mathrm{P}$ contents of roots ( $r=0.997, P=0.01)$ as well as between root biomass and $\mathrm{N}$ content $(r=0.955, P=0.01)$ with increasing $\mathrm{Cd}$ substrate concentrations. Plant growth can decrease the toxic effect of $\mathrm{Cd}$ by dilution.

The $\mathrm{S}$ contents of shoots were higher in Cd-treated plants than in controls except at the highest $\mathrm{Cd}$ concentrations. The $\mathrm{S}$ content of roots were also higher in Cd-treated plants than in the controls up to 25

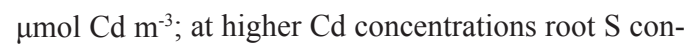
tent decreased (including total $\mathrm{S}$ content). The lowest shoot $\mathrm{S}$ contents of the highest $\mathrm{Cd}$ concentrations may be related to the decreasing S-PTI seen in these plants, in contrast to the others. Gomes et al. (2011b) also report decreases in the S-PTI of willow plants grown in heavy metal-contaminated soils; S uptake, however was not affected. Our data, to the contrary, suggested that $\mathrm{S}$ uptake was restricted in E. camaldulenses plants grown in $\mathrm{Cd}$ substrate concentrations

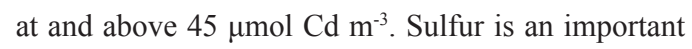
component of amino acids and is required for plant growth (Wiedenhoeft, 2006). A positive correlation was observed between $\mathrm{S}$ content and biomass production in shoots at $\mathrm{Cd}$ concentrations up to $25 \mu \mathrm{mol} \mathrm{m} \mathrm{m}^{-3}$ ( $r=0.961, P=0.05$ ) while a negative correlation was seen between both factors at the highest $\mathrm{Cd}$ treatment ( $r=-0.944, P=0.05$ ), reinforcing the importance of $\mathrm{S}$ in promoting plant growth. $\mathrm{N}, \mathrm{P}$, and $\mathrm{S}$, are also involved in the synthesis of Cd-detoxifying chelator molecules such as gluthatione and phytochelatins (Rosen, 2002) as well as the proliferation of antioxidant systems (i.e. superoxide dismutase, ascorbate peroxidase, and cat- alase) that can mitigate oxidative stress and prevent membrane damage (Wang et al., 2009). The higher S contents of roots at the highest $\mathrm{Cd}$ concentrations may be linked to this factor. The effective distribution of these elements may be one of the main physiological features related to $\mathrm{Cd}$ tolerance in E. camaldulenses.

The $\mathrm{K}, \mathrm{Ca}$, and $\mathrm{Mg}$ contents decreased in $\mathrm{Cd}-$ treated plants but remained higher in shoots than roots. Decreases in total $\mathrm{K}, \mathrm{Ca}$, and $\mathrm{Mg}$ contents probably indicated competition for bivalent ion binding sites by Cd (Kabata-Pendias, 2000). K is preferentially transported to the shoots and has close relationships with protein synthesis, cytokinin supplies, and plant growth, and also serves as an important cation for counterbalancing anions in plants. The increased K-PTI of plants at the highest Cd treatment indicates that this element was necessary in shoots where the $\mathrm{Cd}$ contents were highest, which is supported by the positive correlations between shoot $\mathrm{Cd}$ and $\mathrm{K}$ contents $(r=0.975, P=0.05)$. Changes in shoot translocation of $\mathrm{K}$ and other nutrients have also been attributed to alterations in the vascular system and to reductions in the numbers and diameters of the xylem elements (Ouzounidou, 1994), as were seen here. The positive effects of $\mathrm{K}$ on growth in the presence of $\mathrm{Cd}$ were particularly visible in the positive correlation of amount of this element with biomass production ( $r=0.945, P=0.05 ; r=0.998, P=0.01)$ and Cd content $(r=0.969 ; r=0.046, P=0.05)$ in the roots of plants ex-

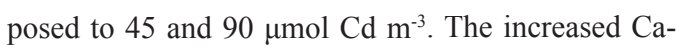
PTI of Cd-treated plants may be explained by its effects in alleviating $\mathrm{Cd}$ toxicity due to the fact high $\mathrm{Ca}$ concentrations near ion channels would decrease $\mathrm{Cd}$ influx (Sarwar et al., 2010) through competition for absorption sites (Clemens et al., 1998). As Mg serves as the central atom of the chlorophyll molecule and as a co-factor in many enzymes activating phosphorylation processes ( $\mathrm{Tu}$ and $\mathrm{Ma}, 2005$ ), the increased MgPTI in plants at the highest $\mathrm{Cd}$ concentrations may 
ensure the maintenance of chlorophyll biosynthesis and avoid further damage to the photosynthetic system, which is supported by the lesser restrictions of shoot growth.

Micronutrient ( $\mathrm{Fe}, \mathrm{Zn}, \mathrm{Cu}$ and $\mathrm{Mn}$ ) contents were higher in roots than shoots, and $\mathrm{Fe}$ and $\mathrm{Cu}$ had similar uptake and distribution patterns. $\mathrm{Fe}$ and $\mathrm{Cu}$ metabolism appear to be associated in plants, and it has been suggested that $\mathrm{Fe}$ modulates $\mathrm{Cu}$ uptake (Lesuisse and Labbe, 1992). Decreasing micronutrient transport to shoots has been reported upon exposure to $\mathrm{Cd}$ (Sandalio et al., 2001), and the alleviation of Cd-phytotoxic effects by $\mathrm{Fe}$ (Shao et al., 2007), Zn (Aravind et al., 2009), and Mn (Baszynski et al., 1980) have been reported. $\mathrm{Fe}$ is an integral cofactor of antioxidant enzymes such as catalase and ascorbate peroxidase (Sharma et al., 2004), and the high Cd contents seen in roots may lead to increased production of phytochelatins that could sequester $\mathrm{Fe}$ as well as $\mathrm{Cd}$. The $\mathrm{Fe}$ and $\mathrm{Cd}$ contents were positively correlated in roots at both of the highest $\mathrm{Cd}$ treatment $(r=0.934 ; r=0,919$, $p=0.05)$. Likewise, $\mathrm{Zn}$ can reduce the production of free radicals released in response to $\mathrm{Cd}$ exposure (Aravind et al., 2009), and $\mathrm{Mn}$ is associated with lignin synthesis (Humphries et al., 2007) and therefore with heavy metal retention in the roots (Lux et al., 2004; Gomes et al., 2011b).

\section{Conclusions}

The eucalyptus species examined (E. camaldulenses) demonstrated tolerance to high soluble Cd-concentrations that was associated with changes in both anatomical and physiological features of these plants. In addition to the high biomass production of this species, it shows significant potential for use in Cd phytoremediation programs.

\section{Acknowledgements}

Authors are grateful to the Fundação de Amparo à Pesquisa do Estado de Minas Gerais (FAPEMIG) for financial support.

\section{References}

Aravind. P., Prasad, M. N. V., Malec, P., Waloszek, A., Strzaka, K. 2009. Zinc protects Ceratophyllum demersum L. (free-floating hydrophyte) against reactive oxygen species induced by cadmium. J. Trace Elem. Med. Biol. 23, 50-60.

Barceló, J, Vázquez, M. D., Poshenrieder, C.H. 1990. Plant water relations as affected by heavy metal stress: a review. J. Plant Nutr. 13, 1-37.

Baszynski, T., Wajda, L., Krol, M., Wolinska, D., Krupa, Z., Tukendorf, A. 1980. Photosynthetic activities of cadmium-treated tomato plants. Physiol. Plant 48, 365-370.

Bernal, M. P., Clemente, R., Walker, D. J. 2009. Interaction of heavy metals with soil organic matter in relation to phytoremediation. In: J. P. NavarroAviño (Ed.), Phytoremediarion: The Green Salvation of the World. Pp. 109-129. Trivandrum, India: Research Signpost.

Campbell, W. H. 1999. Nitrate reductase structure, function and regulation: bridging the gap between biochemistry and physiology. Annu. Rev. Plant Physiol. Plant Mol. Biol. 50, 277-303.

Carlquist, S. 1975. Ecological strategies of xylem evolution. Berkeley: University of California Press.

Chaffei, C., Pageau, K., Suzuki, A., Gouia, H., Ghorbel, M. H., Masclaux-Daubresse, C. 2004. Cadmium toxicity induced changes in nitrogen management in Lycopersicon esculentum leading to a 
metabolic safeguard through an amino acid storage strategy. Plant Cell Physiol. 45, 1681-1693.

Clark, R.B. 1975. Characterization of phosphates in intact maize roots. J. Agric. Food. Chem. 23, 458-460.

Clemens, S., Antosiewez, D. M., Ward, J. M., Schatman, D. P., Schroeder, J. I. 1998. The plant cDNA LCT1 mediates the uptake of calcium and cadmium in yeast. Proc. Nati Academy Sci. 95, 12043-12048.

Dary, M., Chamber-Pérez, M. A., Palomares, A. J., Pejuelo, E. 2010. 'In situ' phytostabilisation of heavy metal polluted soils using Lupinus luteus inoculated with metal resistant plant-growth promoting rhizobacteria. J. Hazard. Mater. 177, 323-330.

Dickison, W. C. 2000. Ecological anatomy. In Dicksison, W.C (ed) Integrative plant anatomy. Academic Press, San Diego, CA, USA, pp 295-344.

Gomes, M. P., Marques, T. C. L. L. S. M., Nogueira, M. O. G., Castro, E. M., Soares, A. M. 2011a. Ecophysiological and anatomical changes due to uptake and accumulation of heavy metal in Brachiaria decumbens. Scientia Agricola. 68, 566-573.

Gomes, M. P., Marques, T. C. L. L. S. M., Silva, G. H., Soares, A. M. 2011b. Utilization of Willow (Salix humboldtiana Willd) as a phytorremediator species of zinc industry waste. Scientia Forestalis. $39,117-123$.

Hassan, M. J., Shao, G., Zhang, G. 2005. Influence of cadmium toxicity on antioxidant enzymes activity in rice cultivars with different grain $\mathrm{Cd}$ accumulation. J. Plant Nutri. 28, 1259-1270.

Hernandez, L. E., Garate, A., Carpena-Ruiz, R. 1997. Effects of cadmium on the uptake, distribution and assimilation of nitrate in Pisum sativum. Plant and Soil 189, 97-106.

Humphries, J., Stangoulis, J., Graham, R. 2007. Manganese. In: Barker A, Pilbeam D (eds), Handbook of Plant Nutrition, Taylor and Francis, USA, pp 351-366.

Kabata-Pendias, A. 2000. Trace elements in soils and plants. Boca Raton: CRC Press.

Krishnamurthy, P., Ranathunge, K., Nayak, S., Schreiber, L., Mathew, M. K. 2011. Root apoplastic barriers block $\mathrm{Na}^{+}$transport to shoots in rice (Oryza sativa L.). J. Exp. Bot. 62, 4215-4228.

Lesuisse, E., Labbe, P. 1992. Iron reduction and transplasma membrane transfer in the yeast Saccharomyces cerevisiae. Plant Physiol. 100, 769-777.

Lux, A. A., Sottniková, A., Opatrná, J., Greger, M. 2004. Differences in struture of adventitions roots in Salix clones with contrasting characteristics of cadmium accumulation and sensitivity. Physiol. Plant. 120, 537-545.

Macnicol, R. D., Beckett, P. H. T. 1985. Critical tissue concentrations of potentially toxic elements. Plant Soil 85, 107-129.

Malavolta, E., Vitti, G. C., Oliveira, S. A. 1989. Avaliação do estado nutricional de plantas: princípios e aplicações. Piracicaba:Potafos.

Marchial, L., Leita, L., Martin, M., Peressotti, A., Zerbi, G. 1996. Physiological responses of two soybeans cultivars to cadmium. J. Environ. Qual. $25,562-566$.

Masclaux, C., Valadier, M., Brugière, N., Morot-Gaudry, J., Hirel, B. 2000. Characterization of the sink/source transition in tobacco (Nicotiana tabacum L.) shoots in relation to nitrogen management and leaf senescence. Planta 211, 510-518.

Moral, R., Gomez, I., Navarro, P., Matrix, J. 1994. Effects of cadmium on nutrient distribution, yield and growth of tomato grown in soilless culture. J. Plant Nutri. 17, 953-962.

Ouzounidou, G. 1994. Copper-induced changes on growth, metal content and photosynthetic func- 
tion of Alyssum montanum L. plants. Environ. Exp. Bot. 34, 165-172.

Paiva, H. N., Carvalho, J. G., Siqueira, J. O. 2000. Efeito de $\mathrm{Cd}, \mathrm{Ni}, \mathrm{Pb}$ e $\mathrm{Zn}$ sobre mudas de cedro (Cedrella fissilis Vell.) e de ipê-roxo (Tabebuia impetiginosa (Mart.) Standley) em solução nutritiva. Rev. Árvore. 24, 369-378.

Pence, N. S., Larsen, P. B., Ebbs, S. D., Letham, D. L. D., Lasat, M. M., Garvin, D. F., Eide, D., Kochian, L.V. 2000. The molecular physiology of heavy metal transport in the $\mathrm{Zn} / \mathrm{Cd}$ hyperaccu-mulator Thlaspi caerulescens. PNAS 97, 4956-4960.

Rivetta, A., Negrini, N., Cocucci, M. 1997. Involvement of $\mathrm{Ca}^{2+}$-calmodulin in $\mathrm{Cd}^{2+}$ toxicity during the early phase of radish (Raphanus sativus L.) seed germination. Plant Cell Environ. 20, 600-608.

Rosen, B. P. 2002. Biochemistry of arsenic detoxification. FEBS Lett. 529, 86-92.

Sandalio, L. M., Dalurzo, H. C., Gómes, M., Romero-Puertas, M. C., Del Rio, L. A. 2001. Cadmiuminduced changes in the growth and oxidative metabolism of pea plants. J. Exp. Bot. 52: 2115-2126.

Shao, G., Chen, M., Wang, W., Mou, R., Zhang, G. 2007. Iron nutrition affects cadmium accumulation and toxicity in rice plants. Plant Grow. Regul. $53,33-42$.

Sharma, R. K., Agrawal, M. 2006. Single and combined effects of cadmium and zinc on carrots: uptake and bioaccumulation. J. Plant Nutri. 29, 1791-1804.
Shi, G., Cai, Q. 2009. Cadmium tolerance and accumulation in eight potential energy crops. Biotech. Adv. 27, 555-561.

Silva, F.C. 1999. Manual de análises químicas de solos, plantas e fertilizantes. Brasília: EMBRAPA. 370p.

Soares. C, R. F. S., Siqueira, J. O., Carvalho, J. G., Moreira, F. M. S. 2005. Fitotoxidez de cádmio para Eucalyptus maculata e E. urophylla em solução nutritiva. Revista Árvore. 29, 175-183.

Tu, C., Ma, L. Q. 2005. Effects of arsenic on concentration and distribution of nutrients in the fronds of the arsenic hyperaccumulator Pteris vittata $\mathrm{L}$. Environ. Pollut. 135, 333-340.

Wang, C., Zhang, S. H., Wang, P. F., Hou, J., Zhang, W. J., Li, W., Lin, Z. P. 2009. The effect of excess $\mathrm{Zn}$ on mineral nutrition and antioxidative response in rapeseed seedlings. Chemosphere. 75 , 1468-1476.

Wiedenhoeft, C. A. 2006. Plant Nutrition. Chelsea House, New York.

Wójcik, M., Vangronsveld, J., D’Haen, J., Tukiendorf, A. 2005. Cadmium tolerance in Thlaspi caerulescens. Environ. Exp. Bot. 53, 163-171.

Zhao, F. J., Lombi, E., McGrath, S. P. 2003. Assessing the potential for zinc and cadmium phytoremediation with the hyperaccumulator Thlaspi caerulescens. Plant and Soil 249, 37-43.

Zhu, Y. L., Zyaed, A. M., Qian, J. H., Souza, M., Terry, N. 1999. Phytoaccumulation of trace elements by wetland plants: II. Water hyacinth. J. Environ. Qual. 28, 339-344. 
